\title{
Genetics and Biotechnology
}

http:/www.journals.zu.edu.eg/journalDisplay.aspx?Journalld=1\&queryType=Master

\section{MOLECULAR MARKERS OF DIFFERENT TOMATO GENOTYPES}

\author{
Ahmed O.M. El-Argaa", S.S.A. Soliman, Mahasin S. Sayed-Ahmed and M.A.H. Yousef \\ Genet. Dept., Fac. Agric., Zagaig Univ., Egypt
}

Received: 17/05/2017 ; Accepted: 24/07/2017

\begin{abstract}
The present study aimed to identify the molecular markers as well as the effects of genotype, explant and hormone balance on the ability of shoot regeneration in vitro tomato propagation. Six commercial cultivars (SM, UC97-3, CR, SQ, SSB and RS) and four hybrids $(\mathrm{SM} \times \mathrm{CR}, \mathrm{SSB} \times \mathrm{CR}, \mathrm{RS} \times \mathrm{CR}$ and $\mathrm{SQ} \times \mathrm{CR})$ were used as different genotypes. Two explant types (shoot tip, eypocotyl) and three media composition [M1 (MS + BA $2 \mathrm{mg} / 1+\mathrm{Kin} 1 \mathrm{mg} / \mathrm{l}$ ), M2 (MS + BA $0.5 \mathrm{mg} / 1+\mathrm{Kin} 0.5 \mathrm{mg} / \mathrm{l}$ ), and $\mathrm{M} 3$ (MS + BA1 mg/l + Kin2 mg/l.)] affected shoot regeneration in all the tested genotypes. The three types of media promoted the shoot tip explant to produce shoots. Only M1 medium promoted the eypocotyl explant to produce shoots. Three criteria were measured on all produced plantlets (leaf number, plant height and number of shoots/ explant). Three genotype(SM, UC97-3, CR and RS) showed the highest number of shoots, number of leaves and plant height, respectively as a response to the culture medium M1 $(2 \mathrm{mg} / \mathrm{l} \mathrm{BA}+1 \mathrm{mg} / \mathrm{l} \mathrm{kin})$ So, they are good combiners for the production of hybrids. The hybrid $(\mathrm{SM} \times \mathrm{CR})$ possessed high number of shoots. Ten ISSR primers were individually amplified to allow the differentiation of the materials under study. All ten primers generated 98 DNA bands, with an average of 9.8 per primer and 78 being polymorphic, The profiles generated by primer $17898 \mathrm{~B}$ (CA) 6GT contained the highest number of polymorphic bands (12 bands). All primers detected unique bands except HB13and HB10 primers. The two varieties $(\mathrm{SM})$ and $\mathrm{UC}_{97-3}$ possessed highly shoot regeneration than the other genotypes and they had unique bands may be used as molecular markers for highly shoot regeneration. These molecular markers were 917 bp by primer 17899 A (CA) 6 AG, 365 bp, 333 bp and 291 bp by 17898 A(CA) $6 \mathrm{AC}$ and $515 \mathrm{bp}$ and $343 \mathrm{bp}$ by primer $17898 \mathrm{~B}$ (CA) 6GT. The evaluation of the dendrogram showed $79 \%$ similarity between SSB and $\mathrm{UC}_{97-3}$ cultivars and they are located in a separate group, and $82 \%$ similarity between CR, SQ, RS, SM cultivars. From the results obtained in this study, ISSR markers have a high efficiency to differentiate the tomato cultivars. Three primers i.e., 17899 A (CA) 6 AG, $17898 \mathrm{~A}(\mathrm{CA}) 6 \mathrm{AC}$ and $17898 \mathrm{~B}(\mathrm{CA}) 6 \mathrm{GT}$ consider as a specific primers in tomato genotypes for discovery of molecular markers to high ability shoot regeneration genotypes.
\end{abstract}

Key words: Molecular, markers, tomato, genotypes.

\section{INTRODUCTION}

Tomato (Lycopersicon esculentum Mill.) is a major vegetable crop that has achieved tremendous popularity over the last century. It is grown in almost all countries of the world-in the field, greenhouses and net houses. The tomato crop is very versatile and is grown either for fresh market or p. Tomato production and consumption has grown quite rapidly over the past 25 years. The world dedicated 4.8 million hectares in 2012 for tomato cultivation and the total production was about 161.8 million tonnes. The average world farm yield for tomato was 33.6 tonnes per hectare, in 2012 (FAO, 2012). Tomato belongs to the family Solanaceae. The botanical name of tomato is Lycopersicon esculentum Mill. It is a diploid plant with $2 \mathrm{n}=24$ chromosomes. Tomato by its nature is a perennial plant, but is commercially cultivated as an annual crop. Greenhouse tomatoes are generally indeterminate and require trellising.

\footnotetext{
*Corresponding author: Tel.: +201005956666

E-mail address: mody_ahmed202060@yahoo.com
} 
Cultivars used in commercial fresh market production under field conditions are determinate and are much shorter in stature than the indeterminate types. Determinate types are easier to harvest and have more concentrated fruit maturity (Rhodes, 2002).

Hybrid tomato varieties have many advantages compared to self-pollinated varieties. Hybrids usually produce higher yields. They generally mature earlier and more uniformly. Many hybrids have better fruit quality and disease resistance, with all of these advantages, many farmers prefer to sow hybrid seeds in spite of the higher seed costs.

Because the hybridization process is carried out manually. The primary goals of in vitro propagation of tomato include the clonal propagation of a large number of genetically identical plants (George and Sherrington 1984). Production of virus-free plant material (Holdgate, 1977) and crop improvement through various genetic techniques seems to be promising.

Since the early observation by Skoog and Miller (1957) that organogenesis is regulated by the balance of auxin and cytokinin in the culture medium, a lot of progress has been made to identify factors that control plant morphogenesis. In earlier studies, attention had been focused on determining the requirements of various plant growth with substances and nutrients for different organogenic processes (Murashige, 1974; Gamborg et al., 1977). More recently a number of investigations on organogenesis have been conducted from a physiological perspective to analyze various cellular processes associated with organogenesis (Tran et al., 1986; Thrope, 1993).

Another way for increase of regeneration efficiency were identify of genotypic differences in plant regeneration capacity. Moghaieb et al. (1999) studied the plant regeneration from eypocotyl and cotyledon of three tomato cultivars, i.e., UC 97, Pontaroza and Zuishi. They reported that the highly significant differences in shoot induction between cultivars were due to the genetic differences between them. The different effects of genotypes on callus and shoot formation were reported by many investigations (Kurtz and Lineberger, 1983; Schutze and Wieczorrek, 1987; Davis et al., 1994 ; Plastira and Perdikaris, 1997).

Rare trials were carried for study the inheritance of plant regeneration ability in tomato, Koornneef (1987) reported that the regeneration capacity from established callus culture of interspecific tomato hybrid (Lycopersicon pervianum $\times$ L. esculentum) was controlled by two dominant genes and the genes controlling shoot regeneration in tomato were characterized and mapped by Koornneef et al. (1993).

Molecular tools facilitate the identification of genomic locations linked to traits of interest and help in indirect selection of such complex traits without the need for difficult phenotypic measurements. In the last few decades, new DNA molecular markers, based on the PCR technique, such as RAPD-PCR and ISSR among others, have become excellent tools for plant breeders (RAPD; Williams et al., 1990)

The present study aimed to determine the response of different genotypes (varieties and hybrids) for plant regeneration and production of more plantlets from one seed hybrid as well as the effect of growth hormone balance and explants on plant regeneration in addition to discover the molecular markers related to high response of genotypes for plant regeneration.

\section{MATERIALS AND METHODS}

This research was done at the tissue culture laboratory of the Department of Genetics, Faculty of Agriculture, Zagazig University.

\section{Plant Material}

Six tomato cultivars were used in this study (Table 1). Seeds of cultivars were kindely provided by Prof. Dr. Abd El-Moniem A. Gad, Professor of Vegetables, Faculty of Agriculture, Zagazig University.

\section{Hybridization}

Seeds of cultivars were sown in greenhouse by multi pot transplant trays filled with a mixture of peat-moss and vermiculite $(1: 1, V / V)$ 
Zagazig J. Agric. Res., Vol. 44 No. (5) 2017

Table 1. The origins and characterization of tomato cultivars under study

\begin{tabular}{llll}
\hline Code & Name & Origin & \multicolumn{1}{c}{ Characterization } \\
\hline SSB & Super Strain B & USA & Determinate, very firm, processing, fresh market \\
SM & Supermarmand & France & Semi-determinate, very firm, processing, fresh market \\
CR & Castle Rock & RS & Determinate, medium firm, heat tolerant, fresh market \\
SB & Strain B & Holland & Determinate, medium firm, fresh market \\
UC & UC & USA-3 & D Determinate, very firm, processing, fresh market \\
SQ & SUPPER QEEN & USA & Determinate, very firm, processing, fresh market \\
\hline
\end{tabular}

media. After one month from sowing, transplants were transferred to the filed under low tunnels.

Crosses were made between these parents to obtain 4 hybids. Crosses were made between these cultivars $\mathrm{SM} \times \mathrm{C} . \mathrm{R}, \mathrm{SSB} \times \mathrm{CR}, \mathrm{RS} \times \mathrm{CR}$, and $\mathrm{SQ} \times \mathrm{CR}$.

\section{Measurements for Plantlets In vitro Propagation}

In the present study the plant height $(\mathrm{cm})$, number of leaves and number of shoots were measured inside the laminar flow under sterilized conditions.

\section{In vitro propagation (tissue culture)}

Tomato seeds were surface sterilized by $60 \%$ commercial Clorox (contain 5.25\% sodium hypochlorite) for $15 \mathrm{~min}$ followed by washing three times with sterilized distilled water. Aseptically seeds were transferred to $300 \mathrm{ml}$ glass jar containing $40 \mathrm{ml}$ of basal MS medium (Murashige and Skoog, 1962), Culture medium was adjusted to $\mathrm{pH} 5.7$ before autoclaving at $121^{\circ} \mathrm{C}$ and $1.5 \mathrm{~kg} / \mathrm{cm}^{2}$ for $20 \mathrm{~min}$. Seeds were cultured on previously prepared media and then incubated at $25^{\circ} \mathrm{C}$ for three days in darkness. The culture were transferred to growth chamber provide with $16 \mathrm{hr}$., photoperiod (1000 - 2000 Iux) and $8 \mathrm{hr}$., dark. Germinated seeds were used to obtain the shoot tip and eypocotyls explants which transferred to three different types of plant regeneration media.

1. MS + BA 2mg/1 + Kin1 mg/l. (M1) (Kamel, 2004)
2. $\mathrm{MS}+\mathrm{BA} 0.5 \mathrm{mg} / 1+\mathrm{Kin} 0.5 \mathrm{mg} / \mathrm{l}$. (M2)

3. MS + BA1mg/l + Kin 2 mg/1. (M3)

\section{Molecular Genetic Studies}

\section{DNA extraction}

DNA was extracted from leaves using the CTAB method described by Doyle and Doyle (1987) as modified by Khaled and Esh (2008). Inter simple sequence Repeats polymerase chain reaction (ISSRs - PCR). Ten ISSR primers were used in this study. The primers names and sequences are shown in Table 2.

\section{Polymerase chain reaction (PCR)}

Polymerase chain reaction (PCR) conditions were optimized and mixtures were prepared in a final volume of $12.5 \mu \mathrm{l}$ using Fermentas taq polymerase containing $1.3 \mu 110 \mathrm{X}$ buffer, $0.4 \mu 1$ dNTPs, $0.2 \mu 1$ Taq DNA polymerase (5 unit/1 $\mu 1), 0.6 \mu 1$ Template DNA, $1.0 \mu$ Primer and up to $12.5 \mu \mathrm{l} \quad \mathrm{H}_{2} \mathrm{O} \quad(\mathrm{dd})$.The amplification was performed for (35) cycles. Ten primers were used in this study (Table 2).

PCR amplification products were analyzed electrophoretically on $1.5 \%$ agarose gels in $1 \mathrm{X}$ TBE buffer. A fermentas $1 \mathrm{Kbp}$ Xygene DNA ladder separate to twelve fragments with molecular sizes 300, 500, 1000, 1500, 2000, $2500,3000,4000,5000,6000,8000$ and $10000 \mathrm{bp}$ were used. The run was reformed in $1.5 \%$ agarose gel at $80 \mathrm{v}$ and the fragments were detected on UV transelumenator and photographed with Gel documentation (BioRad system). 
Table 2. Primer names and their sequences for ISSR - PCR analysis

\begin{tabular}{llllll}
\hline No. & Primer code & Sequence & No. & Primer code & Sequence \\
\hline ISSR 1 & $17899 \mathrm{~A}$ & $(\mathrm{CA}) 6 \mathrm{AG}$ & ISSR 6 & 814 & (CT)8TG \\
ISSR 2 & $17898 \mathrm{~A}$ & $(\mathrm{CA}) 6 \mathrm{AC}$ & ISSR 7 & HB 12 & (CAC)3GC \\
ISSR 3 & $17898 \mathrm{~B}$ & $(\mathrm{CA}) 6 \mathrm{GT}$ & ISSR 8 & HB15 & (GTG)3GC \\
ISSR 4 & $844 \mathrm{~A}$ & $(\mathrm{CT}) 8 \mathrm{AC}$ & ISSR 9 & HB13 & (GAG)3GC \\
ISSR 5 & $844 \mathrm{~B}$ & $(\mathrm{CT}) 8 \mathrm{GC}$ & ISSR 10 & HB10 & (GA)6CC \\
\hline
\end{tabular}

The amplification was performed for (35) cycles as follows:

Initial denaturation $\quad 94^{\circ} \mathrm{c}$ for $2 \mathrm{~min}$. $94^{\circ} \mathrm{c}$ for $30 \mathrm{sec}$. $38^{\circ} \mathrm{c}$ for $30 \mathrm{sec}$. $72^{\circ} \mathrm{c}$ for $2 \mathrm{~min}$.

Final extension $72^{\circ} \mathrm{c}$ for $5 \mathrm{~min}$. $4^{\circ} \mathrm{c}$ (infinite) one cycle

\begin{tabular}{l}
35 cycles \\
\hline one cycle
\end{tabular}

\section{Statistical Analysis}

All studied characters were analyzed by ANOVA with excel program 2011 with two factors according to Gomez and Gomez (1984). Heritability and component of variation were calculated according to Singh et al. (1987).

\section{RESULTS AND DISCUSSION}

\section{Response of Genotypes Under Different Levels of Hormones Balance and Explants for Plant Regeneration}

Highly significant differences between genotypes, and media for number of shoots, explants, number of leaves and plant height of plantlets, except number of leaves at 30 days were found. In addition interaction between genotypes and media. High heritability of these three criteria under study, except number of leaves at 30 days. These results confirmed the useful selection for highest ability of shoot regeneration through choosing optimum combination between the varieties and growth hormone balance (Table 3).

The present study confirmed that the varieties SM, UC97-3, CR and RS showed the highest number of shoots, as a response to the culture medium M1 (2mg/l BA $+1 \mathrm{mg} / 1 \mathrm{kin})$
(Table 4). So they are good combiners for the production of hybrids by using this medium, also the hybrid $(\mathrm{SM} \times \mathrm{CR})$ possessed high number of shoots compared to the rest hybrids (Table 4), this results showed no considerable differences after 15 days than 30 days after explants culture. The same results appeared in the case of number of leaves and plant height (Table 5) which indicate that those varieties could be used in the programs of hybrid seed production. Also these results indicated that the M1 medium was the best combination of growth regulator for the production of tomato plantlets by using direct micropropagation technique when shoot tip is used as initial explants. When eypocotyls is used as initial explants, only the M1 media promoted, the explants to proliferate to plantlets while M2 $(0.5 \mathrm{mg} / \mathrm{l} \mathrm{BA}+1 \mathrm{mg} / \mathrm{l} \mathrm{kin})$ and M3 (1mg/l BA $+2 \mathrm{mg} / \mathrm{l} \mathrm{kin)} \mathrm{did} \mathrm{not} \mathrm{promote}$ the eypocotyls explants to produce direct plantlets, where the varieties SM and UC97-3 showed the highest number of shoots and number of leaves as a response to the culture medium M1 (2 mg/l BA +1mg/l kin). While in the case of plant height the varieties $\mathrm{CR}$ and UC97-3 showed the highest result (Table 6). By using eypocotyle as explant, highly significant differences between genotypes for number of shoots, plant height and number of 
Table 3. Mean sum of squares (MS) for number of shoots, number of leaves and plant height using shoot tip explants in direct micropropagation

\begin{tabular}{|c|c|c|c|c|c|c|c|}
\hline \multirow[t]{3}{*}{$\overline{\text { SOV }}$} & \multirow[t]{3}{*}{ df } & \multicolumn{6}{|c|}{ MS } \\
\hline & & \multicolumn{2}{|c|}{ Number of shoots } & \multicolumn{2}{|c|}{ Number of leaves } & \multicolumn{2}{|c|}{ Plant height(cm) } \\
\hline & & 15 days & 30 days & 15 days & 30 days & 15 days & 30 days \\
\hline Replication & 2 & 0.74 & 0.28 & 0.94 & 0.90 & 0.76 & 0.68 \\
\hline Genotypes(G) & 9 & $2.59^{* *}$ & $3.27^{* *}$ & $63.57^{* *}$ & 10.30 & $0.63^{* *}$ & $1.85^{* *}$ \\
\hline Media (M) & 2 & $2.77^{* *}$ & $4.345^{* *}$ & $41.587^{* *}$ & $36.36^{* *}$ & $0.65^{* *}$ & $1.55^{* *}$ \\
\hline $\mathbf{M} \times \mathbf{G}$ & 18 & $2.58^{* *}$ & $3.27^{* *}$ & 0.17 & 20.2 & $0.25^{*}$ & $0.39^{* *}$ \\
\hline Error & 58 & 0.313 & 0.73 & 2.8 & 12.54 & 0.12 & 0.059 \\
\hline $\mathbf{H}^{2}$ & & 92.2 & 86 & 91.6 & 60.3 & 80.8 & 95.2 \\
\hline
\end{tabular}

* Significant at $0.05 * *$ Significant at 0.01

Table 4. Average mean and LSD for number of shoots per explant at $\mathbf{1 5}$ and $\mathbf{3 0}$ days from culture of different genotypes using shoot tip explants in direct micropropagation

\begin{tabular}{|c|c|c|c|c|c|c|c|c|c|c|c|c|}
\hline & & $\overline{\mathbf{S M}}$ & $\mathbf{R S}$ & $\mathbf{C R}$ & SQ & $\mathrm{UC}_{97-3}$ & SSB & $\mathbf{S M} \times \mathbf{C R}$ & $\mathbf{S S B} \times \mathbf{C R}$ & $\mathbf{R S} \times \mathbf{C R}$ & $\mathbf{S Q} \times \mathbf{C R}$ & $\begin{array}{c}\text { General mean } \\
\text { for media }\end{array}$ \\
\hline \multirow{2}{*}{ (BA2mg/l+ Kin1mg/l) } & 15 days & 5.33 & 2.33 & 2.67 & 3 & 5.33 & 2 & 2.33 & 1 & 1 & 1 & 2.599 \\
\hline & 30 days & 5.67 & 3 & 3.67 & 3.67 & 6 & 1.67 & 3 & 1 & 1 & 1 & 2.968 \\
\hline \multirow{2}{*}{ (BA0.5 mg/l + Kin 0.5mg/l) } & 15 days & 1 & 1 & 1 & 1 & 1 & 1 & 1 & 1 & 1 & 1 & 1 \\
\hline & 30 days & 1 & 1 & 1 & 1 & 1 & 1 & 1 & 1 & 1 & 1 & 1 \\
\hline (BA1mg/l +Kin2mg/l) & 30 days & 1 & 1 & 1 & 1 & 1 & 1 & 1 & 1 & 1 & 1 & 1 \\
\hline General mean for genotypes & & 2.5 & 1.56 & 1.72 & 1.78 & 2.56 & 1.28 & 1.56 & 1 & 1 & 1 & \\
\hline
\end{tabular}

LSD $0.05=0.676$ LSD $0.01=0.902$ 
Table 5. Average mean and LSD for number of leaves at 15 and 30 days from culture of different genotypes using shoot tip explants in direct micropropagation

\begin{tabular}{|c|c|c|c|c|c|c|c|c|c|c|c|c|}
\hline & & SM & $\mathbf{R S}$ & $\overline{C R}$ & SQ & $\overline{\mathrm{UC}_{97-3}}$ & SSB & $\mathbf{S M} \times \mathbf{C R}$ & $\mathrm{SSB} \times \mathrm{CR}$ & $\overline{\mathbf{R S} \times \mathbf{C R}}$ & $\mathbf{S Q} \times \mathbf{C R}$ & $\begin{array}{l}\text { General mean } \\
\text { for media }\end{array}$ \\
\hline \multirow{2}{*}{ (BA2mg/l+ Kin1mg/l) } & 15 days & 14.67 & 6.67 & 8.33 & 9 & 16 & 6 & 8 & 3 & 3 & 3 & 7.77 \\
\hline & 30 days & 17 & 9.67 & 11.67 & 12 & 18.67 & 7 & 6 & 3 & 3 & 3 & 9.1 \\
\hline \multirow{2}{*}{ (BA0.5 mg/l + Kin 0.5mg/l) } & 15 days & 3 & 3 & 3 & 3 & 3 & 3 & 3 & 3 & 3 & 3 & 3 \\
\hline & 30 days & 3 & 3 & 3 & 3 & 3 & 3 & 3 & 3 & 3 & 3 & 3 \\
\hline \multirow{2}{*}{ (BA1mg/l +Kin2mg/l) } & 15 days & 3 & 3 & 3 & 3 & 3 & 3 & 3 & 3 & 3 & 3 & 3 \\
\hline & 30 days & 3 & 3 & 3 & 3 & 3 & 3 & 3 & 3 & 3 & 3 & 3 \\
\hline General mean for genotypes & & 7.28 & 4.72 & 5.33 & 5.5 & 7.78 & 4.17 & 4.33 & 3 & 3 & 3 & \\
\hline
\end{tabular}

Table 6. Average mean and LSD for plant height at 15 and 30 days from culture of different genotypes using shoot tip explants in direct micropropagation

\begin{tabular}{|c|c|c|c|c|c|c|c|c|c|c|c|c|}
\hline & & SM & $\mathbf{R S}$ & $\mathbf{C R}$ & SQ & $\mathrm{UC}_{97-3}$ & SSB & $\mathbf{S M} \times \mathbf{C R}$ & $\mathbf{S S B} \times \mathbf{C R}$ & $\mathbf{R S} \times \mathbf{C R}$ & $\mathbf{S Q} \times \mathbf{C R}$ & $\begin{array}{c}\text { General mean } \\
\text { for media }\end{array}$ \\
\hline \multirow[t]{2}{*}{$\overline{(B A 2 m g / l+~ K i n 1 m g / l) ~}$} & 15 days & 2.67 & 2.25 & 2.5 & 2.17 & 3.13 & 1.67 & 2.67 & 1.67 & 1.6 & 1.67 & 2.2 \\
\hline & 30 days & 3.5 & 2.9 & 2.72 & 2.58 & 3.53 & 2 & 3.5 & 2.9 & 2.72 & 2.58 & 2.89 \\
\hline \multirow[t]{2}{*}{$($ BA0.5mg/l + Kin 0.5mg/l) } & 15 days & 1.73 & 1.63 & 1.7 & 1.43 & 1.8 & 2.17 & 1.85 & 2.17 & 1.7 & 1.7 & 1.79 \\
\hline & 30 days & 2.33 & 2.33 & 1.97 & 2.33 & 2.8 & 2.17 & 2.33 & 2.37 & 1.7 & 1.7 & 2.2 \\
\hline (BA1mg/l +Kin2mg/l) & 30 days & 2.3 & 2.07 & 2 & 1.43 & 2.4 & 2.27 & 2.33 & 2 & 1.8 & 1.67 & 2.03 \\
\hline General mean for genotypes & & 2.48 & 2.23 & 2.15 & 1.95 & 2.69 & 2.09 & 2.5 & 2.19 & 1.55 & 1.84 & \\
\hline
\end{tabular}

LSD $0.05=0.598$ LSD $0.01=0.798$ 
leaves (Table 7). The results of the current experiment showed that both of shoot tip and eypocotyle explants induced shoots directly without passing callus state which is in contrast with many researchers who reported successful callus induction from various tomato explants in the presence of growth regulators (Devi et al., 2008; Ishag et al., 2009). Variations in the callus induction and growth among tomato cultivars induced from different explants and the effect of hormones were reported by many researchers (Abdel-Raheem et al., 2007; Adams et al., 1992; Bhatia et al., 2004).

The same trend was recorded in the ability of genotypes for shoot regeneration when eypocotyle was used as explants. Super marmand (SM), UC97-3 varieties possessed increase ability for shoot regeneration than the other genotypes, as well as insignificant differences between seedling age (15 and 30 days). Therefore the $15^{\text {th }}$ days consider as an optimum stage to subculture for multiplication of propagula. Average mean and LSD for number of shoots, plant height and number of leaves. At 15 and 30 days from culture of different genotypes using eypocotyl explants in direct micropropagation (Tables 8, 9 and 10).

\section{Molecular Genetic Studies}

Ten ISSRs primers were used to characterize the genetic divergence of the six cultivars of $S$. lycopersicon. In Table 12, it is shown the number of amplified bands, the number of monomorphic bands, the number of polymorphic bands, the number of unique bands and the polymorphism percentage obtained. A total of 98 bands were amplified and 78 of them were polymorphic, representing $79.6 \%$ of the amplified bands, 13 of them were unique bands, representing $13.26 \%$ of the amplified bands and 7 of them were monomorphic bands, representing $7.14 \%$ of the amplified bands. The average of the total bands per primer studied was 9.8 , ranging from 5 to 15 bands. The data obtained from the 10 primers showed a high polymorphism degree ranged between $50 \%$ : $100 \%$ (Table 12).

According to statistical analysis both of SM and $\mathrm{UC}_{97-3}$ cultivars showed the highest response to tissue culture and also showed bands with different molecular size that only existed in both of them, these bands were $917 \mathrm{bp}$ by primer 17899 A (CA) 6 AG, 365 bp, 333 bp and 291 bp by $17898 \mathrm{~A}(\mathrm{CA}) 6 \mathrm{AC}$ and $515 \mathrm{bp}$ and $343 \mathrm{bp}$ by primer 17898 B (CA) 6GT (Fig.1 A,B,C and Table 11) which indicated that these bands may be related to the increasing ability for shoot regeneration of direct micropropagation.

ISSR molecular markers have been used successfully in germplasm bank characterization (Kochieva et al., 2002; Tikunov et al., 2003; Terzopoulos and Bebeli, 2008) especially in the assessment of the differences among species or varieties belonging to the same genus. In the current study, the ISSR markers were also useful in the characterization of $S$. lycopersicon cultivars, amplifying a relatively large number of bands per primer, The degree of genetic divergence detected between $S$. lycopersicon cultivars, using these primers, was considered high in comparison to the level of polymorphism among accessions of other species of the genus (Terzopoulos and Bebeli, 2008; Kochieva et al., 2002). However the variation detected was sufficient to distinguish the cultivars in the current study. Within the gender Solanum, members of different species have distinct phenotypic and genotypic characteristics and a high level of polymorphism can be expected among them, but a low level is expected among the members of the same species. However, the observed values are compatible with those obtained by Park et al. (2003), who assessed the genetic diversity of 74 cultivars of $S$. lycopersicon, and by AFLP. Kochieva et al. (2002) who estimated the genetic polymorphism of the genus Solanum using RAPD. The analysis showed that the polymorphism of the representatives of the genus ranged between $65.6 \%-98.8 \%$. The polymorphism accessed by different molecular markers is low when comparing individuals or accessions of the same species of Solanum.

Our finding with ISSR molecular markers tested pointed to some distinguish bands and unique bands (allelic) and could be used as selection tool for highly shoot regeneration.

The similarity coefficient values among all cultivars and new lines based on band polymorphisms generated by ISSR after using the primers (Table 13). Phylogenetic tree displaying the similarity of tomato cultivars. The tree was constructed using (Fig. 2). 
Table 7. Mean sum of squares (MS) for number of shoots, number of leaves and plant height using eypocotyl explants in direct micropropagation

\begin{tabular}{|c|c|c|c|c|c|c|c|}
\hline \multirow[t]{3}{*}{$\overline{\text { SOV }}$} & \multirow[t]{3}{*}{ df } & \multicolumn{6}{|c|}{ MS } \\
\hline & & \multicolumn{2}{|c|}{ Number of shoots } & \multicolumn{2}{|c|}{ Number of leaves } & \multicolumn{2}{|c|}{ Plant height(cm) } \\
\hline & & 15 days & 30 days & 15 days & 30 days & 15 days & 30 days \\
\hline$\overline{\text { Replication }}$ & 2 & 0.23 & 0.64 & 3.1 & 4.15 & 0.1 & 0.23 \\
\hline Treatment & 9 & $1.86^{* *}$ & $2.69^{* *}$ & $15.66^{* *}$ & $32.39^{* *}$ & $0.45^{* *}$ & $0.41^{* *}$ \\
\hline Error & 18 & 0.45 & 0.37 & 3.46 & 4.32 & 0.039 & 0.02 \\
\hline$h^{2}$ in broad sense & & 60 & 75.8 & 77.9 & 76.4 & 81.9 & 90.4 \\
\hline
\end{tabular}

Table 8. Average mean and LSD for number of shoots at 15 and 30 days from culture of different genotypes using eypocotyl explants in direct micropropagation

\begin{tabular}{lcccccccccccc}
\hline & & SM & RS & CR & SQ & UC $_{97-3}$ & SSB & SM $\times$ CR & SSB $\times$ CR & $\begin{array}{c}\text { RS } \times \text { CR } \\
\text { SQ } \times \text { CR General mean } \\
\text { for media }\end{array}$ \\
\hline (BA2mg/l+ Kin1mg/l) & 15 days & 3 & 1.33 & 1.67 & 1 & 3 & 1.33 & 1.33 & 1 & 1 & 1 & 1.56 \\
& 30 days & 4.67 & 3.67 & 2 & 1.33 & 3.33 & 1.5 & 1.67 & 1 & 1.67 & 1 & 2.18 \\
General mean for genotypes & & 3.83 & 2.5 & 1.83 & 1.16 & 3.16 & 1.16 & 1.5 & 1 & 1.33 & 1 & \\
\hline
\end{tabular}

LSD $0.05=1.34$ LSD $0.01=1.83$ 
Table 9. Average mean and LSD for number of leaves at 15 and 30 days from culture of different genotypes using eypocotyl explants in direct micropropagation

\begin{tabular}{|c|c|c|c|c|c|c|c|c|c|c|c|c|}
\hline & & SM & $\mathbf{R S}$ & $\mathbf{C R}$ & SQ & $\overline{U C_{97-3}}$ & SSB & $\mathbf{S M} \times \mathbf{C R}$ & $\mathrm{SSB} \times \mathrm{CR}$ & $\mathbf{R S} \times \mathbf{C R}$ & $\mathbf{S Q \times C R}$ & $\begin{array}{l}\text { General mean } \\
\text { for media }\end{array}$ \\
\hline \multirow{2}{*}{ (BA2mg/l+ Kin1mg/l) } & 15 days & 8.33 & 3.67 & 6 & 3 & 9 & 4 & 4 & 3 & 3 & 3 & 4.7 \\
\hline & 30 days & 11.67 & 6.33 & 6 & 4 & 11.67 & 5 & 5 & 3 & 3 & 3 & 5.86 \\
\hline General mean for genotypes & & 10 & 5 & 6 & 3.5 & 10.33 & 4.5 & 4.5 & 3 & 3 & 3 & \\
\hline
\end{tabular}

LSD $0.05=4.14$ LSD $0.01=5.65$

Table 10. Average mean and LSD for plant height at 15 and 30 days from culture of different genotypes using eypocotyl explants in direct micropropagation

\begin{tabular}{|c|c|c|c|c|c|c|c|c|c|c|c|c|}
\hline & & SM & $\mathbf{R S}$ & $\mathbf{C R}$ & SQ & $\mathbf{U C}_{97-3}$ & SSB & $\mathbf{S M} \times \mathbf{C R}$ & SSB $\times$ CR & $\mathbf{R S} \times \mathbf{C R}$ & $\mathbf{S Q} \times \mathbf{C R}$ & $\begin{array}{l}\text { General mean } \\
\text { for media }\end{array}$ \\
\hline \multirow{2}{*}{$(B A 2 m g / l+K i n 1 m g / l)$} & 15 days & 2.22 & 1.8 & 2.17 & 1.83 & 2.42 & 1.33 & 2.22 & 1.33 & 1.67 & 2.22 & 1.92 \\
\hline & 30 days & 11.67 & 6.33 & 6 & 4 & 11.67 & 5 & 5 & 3 & 3 & 3 & 5.86 \\
\hline General mean for genotypes & & 6.94 & 8.13 & 8.17 & 2.91 & 14.09 & 3.16 & 3.61 & 2.16 & 2.33 & 2.61 & \\
\hline
\end{tabular}


Table 11. Profiles of DNA amplification of 6 S. lycopersicon cultivars (agarose gel 1.5\%, stained with ethidium bromide)

\begin{tabular}{|c|c|c|c|c|c|c|c|c|c|}
\hline Primer & Band & bp & $\mathbf{C R}$ & SSB & RS & SM & $\overline{u c_{97-3}}$ & SQ & Frequency \\
\hline \multirow{9}{*}{ ISSR-1 } & Band 1 & 917 & 0 & 0 & 0 & $\overline{1}$ & $\overline{1}$ & 0 & 0.25 \\
\hline & Band 2 & 865 & 1 & 1 & 1 & 1 & 0 & 0 & 0.67 \\
\hline & Band 3 & 751 & 1 & 0 & 0 & 1 & 0 & 0 & 0.33 \\
\hline & Band 4 & 702 & 0 & 0 & 0 & 0 & 1 & 0 & 0.17 \\
\hline & Band 5 & 659 & 1 & 1 & 1 & 1 & 0 & 0 & 0.67 \\
\hline & Band 6 & 623 & 0 & 1 & 1 & 1 & 0 & 0 & 0.50 \\
\hline & Band 7 & 577 & 1 & 1 & 1 & 0 & 0 & 0 & 0.50 \\
\hline & Band 8 & 517 & 1 & 1 & 1 & 1 & 0 & 0 & 0.67 \\
\hline & Band 1 & 1735 & 0 & 1 & 0 & 0 & 1 & 0 & 0.33 \\
\hline \multirow{10}{*}{ ISSR-2 } & Band 2 & 861 & 1 & 0 & 0 & 0 & 1 & 0 & 0.33 \\
\hline & Band 3 & 798 & 1 & 1 & 0 & 0 & 0 & 0 & 0.33 \\
\hline & Band 4 & 653 & 1 & 0 & 0 & 0 & 0 & 0 & 0.17 \\
\hline & Band 5 & 599 & 1 & 1 & 1 & 0 & 1 & 1 & 0.833 \\
\hline & Band 6 & 498 & 1 & 0 & 1 & 0 & 0 & 0 & 0.33 \\
\hline & Band 7 & 459 & 1 & 1 & 0 & 1 & 0 & 0 & 0.50 \\
\hline & Band 8 & 436 & 0 & 0 & 1 & 0 & 1 & 0 & 0.33 \\
\hline & Band 9 & 356 & 0 & 0 & 0 & 1 & 1 & 0 & 0.33 \\
\hline & Band 10 & 333 & 0 & 0 & 0 & 1 & 1 & 0 & 0.33 \\
\hline & Band 11 & 291 & 0 & 0 & 0 & 1 & 1 & . & 0.33 \\
\hline \multirow{12}{*}{ ISSR-3 } & Band 1 & 1611 & 1 & 1 & 1 & 1 & 1 & 0 & 0.833 \\
\hline & Band 2 & 1354 & 1 & 1 & 1 & 1 & 0 & 1 & 0.33 \\
\hline & Band 3 & 1257 & 0 & 0 & 0 & 0 & 1 & 0 & 0.17 \\
\hline & Band 4 & 872 & 0 & 0 & 0 & 0 & 1 & 0 & 0.17 \\
\hline & Band 5 & 775 & 0 & 0 & 1 & 0 & 0 & 0 & 0.17 \\
\hline & Band 6 & 718 & 0 & 1 & 1 & 0 & 1 & 0 & 0.50 \\
\hline & Band 7 & 617 & 1 & 1 & 1 & 0 & 1 & 1 & 0.833 \\
\hline & Band 8 & 515 & 0 & 0 & 0 & 1 & 1 & 0 & 0.833 \\
\hline & Band 9 & 466 & 0 & 0 & 0 & 0 & 1 & 0 & 0.17 \\
\hline & Band 10 & 413 & 1 & 1 & 1 & 0 & 1 & 0 & 0.67 \\
\hline & Band 11 & 384 & 1 & 1 & 1 & 0 & 1 & 0 & 0.67 \\
\hline & Band 12 & 343 & 0 & 0 & 0 & 1 & 1 & 0 & 0.33 \\
\hline \multirow{7}{*}{ ISSR-4 } & Band 1 & 1005 & 0 & 0 & 1 & 0 & 0 & 0 & 0.17 \\
\hline & Band 2 & 865 & 0 & 0 & 0 & 0 & 1 & 0 & 0.17 \\
\hline & Band 3 & 770 & 0 & 0 & 0 & 0 & 1 & 0 & 0.17 \\
\hline & Band 4 & 668 & 0 & 0 & 1 & 0 & 1 & 0 & 0.33 \\
\hline & Band 5 & 478 & 0 & 1 & 0 & 0 & 0 & 0 & 0.17 \\
\hline & Band 6 & 425 & 0 & 0 & 1 & 0 & 1 & 0 & 0.33 \\
\hline & Band 7 & 350 & 0 & 0 & 1 & 0 & 1 & 0 & 0.33 \\
\hline \multirow{9}{*}{ ISSR-5 } & Band 1 & 1217 & 0 & 1 & 0 & 0 & 0 & 0 & 0.17 \\
\hline & Band 2 & 764 & 0 & 0 & 0 & 0 & 1 & 1 & 0.33 \\
\hline & Band 3 & 676 & 1 & 1 & 0 & 1 & 0 & 0 & 0.50 \\
\hline & Band 4 & 629 & 1 & 1 & 0 & 0 & 1 & 1 & 0.67 \\
\hline & Band 5 & 521 & 1 & 0 & 0 & 0 & 0 & 0 & 0.17 \\
\hline & Band 6 & 471 & 1 & 1 & 1 & 1 & 1 & 1 & 1 \\
\hline & Band 7 & 440 & 0 & 1 & 0 & 0 & 0 & 0 & 0.17 \\
\hline & Band 8 & 369 & 0 & 1 & 0 & 0 & 0 & 0 & 0.17 \\
\hline & Band 9 & 336 & 1 & 1 & 1 & 1 & 1 & 1 & 1 \\
\hline
\end{tabular}


Table 11. Cont.

\begin{tabular}{|c|c|c|c|c|c|c|c|c|c|}
\hline \multirow{5}{*}{ ISSR-6 } & Band 1 & 1129 & 1 & 1 & 0 & 1 & 1 & 1 & 0.67 \\
\hline & Band 2 & 895 & 1 & 1 & 1 & 1 & 1 & 1 & 1 \\
\hline & Band 3 & 617 & 1 & 1 & 1 & 1 & 1 & 1 & 1 \\
\hline & Band 4 & 550 & 0 & 0 & 0 & 0 & 0 & 1 & 0.67 \\
\hline & Band 1 & 1997 & 0 & 1 & 1 & 0 & 1 & 0 & 0.50 \\
\hline \multirow{6}{*}{ ISSR-7 } & Band 2 & 1622 & 0 & 1 & 1 & 1 & 0 & 1 & 0.67 \\
\hline & Band 3 & 1458 & 0 & 0 & 0 & 0 & 1 & 0 & 0.17 \\
\hline & Band 4 & 1043 & 1 & 1 & 1 & 0 & 1 & 1 & 0.833 \\
\hline & Band 5 & 906 & 1 & 1 & 1 & 0 & 1 & 0 & 0.67 \\
\hline & Band 6 & 849 & 1 & 1 & 0 & 1 & 1 & 1 & 0.833 \\
\hline & Band 7 & 799 & 1 & 1 & 1 & 1 & 1 & 1 & 1 \\
\hline \multirow{10}{*}{ ISSR-8 } & Band 8 & 674 & 1 & 1 & 1 & 1 & 1 & 0 & 0.833 \\
\hline & Band 1 & 1675 & 0 & 0 & 0 & 0 & 1 & 0 & 0.17 \\
\hline & Band 2 & 1428 & 1 & 1 & 0 & 0 & 1 & 0 & 0.50 \\
\hline & Band 3 & 1279 & 0 & 1 & 1 & 0 & 0 & 0 & 0.33 \\
\hline & Band 4 & 1020 & 1 & 1 & 1 & 0 & 1 & 1 & 0.833 \\
\hline & Band 5 & 848 & 0 & 0 & 1 & 1 & 0 & 0 & 0.33 \\
\hline & Band 6 & 705 & 0 & 1 & 1 & 1 & 0 & 1 & 0.67 \\
\hline & Band 7 & 616 & 1 & 1 & 1 & 0 & 1 & 1 & 0.833 \\
\hline & Band 8 & 533 & 1 & 1 & 1 & 1 & 1 & 1 & 1 \\
\hline & Band 1 & 1875 & 0 & 0 & 1 & 0 & 1 & 0 & 0.33 \\
\hline \multirow{8}{*}{ ISSR-9 } & Band 2 & 1359 & 0 & 0 & 1 & 0 & 1 & 0 & 0.33 \\
\hline & Band 3 & 1126 & 0 & 1 & 1 & 1 & 0 & 1 & 0.67 \\
\hline & Band 4 & 976 & 0 & 0 & 1 & 1 & 0 & 1 & 0.50 \\
\hline & Band 5 & 921 & 1 & 1 & 0 & 1 & 0 & 1 & 0.67 \\
\hline & Band 6 & 765 & 0 & 1 & 1 & 1 & 0 & 0 & 0.50 \\
\hline & Band 7 & 710 & 0 & 0 & 0 & 1 & 0 & 1 & 0.50 \\
\hline & Band 8 & 660 & 1 & 1 & 1 & 1 & 1 & 1 & 1 \\
\hline & Band 9 & 585 & 1 & 1 & 1 & 1 & 0 & 0 & 0.67 \\
\hline \multirow{9}{*}{ ISSR-10 } & Band 1 & 806 & 1 & 1 & 1 & 1 & 0 & 0 & 0.67 \\
\hline & Band 2 & 631 & 1 & 1 & 1 & 1 & 0 & 0 & 0.67 \\
\hline & Band 3 & 530 & 1 & 1 & 1 & 1 & 0 & 0 & 0.67 \\
\hline & Band 4 & 446 & 1 & 1 & 1 & 1 & 0 & 0 & 0.67 \\
\hline & Band 5 & 404 & 1 & 1 & 1 & 1 & 0 & 0 & 0.67 \\
\hline & Band 6 & 356 & 1 & 1 & 1 & 1 & 0 & 0 & 0.67 \\
\hline & Band 7 & 284 & 1 & 1 & 1 & 1 & 1 & 1 & 1 \\
\hline & Band 8 & 261 & 1 & 1 & 1 & 1 & 1 & 0 & 0.833 \\
\hline & Band 9 & 245 & 1 & 1 & 1 & 1 & 0 & 1 & 0.833 \\
\hline
\end{tabular}


1662

A) ISSR-1

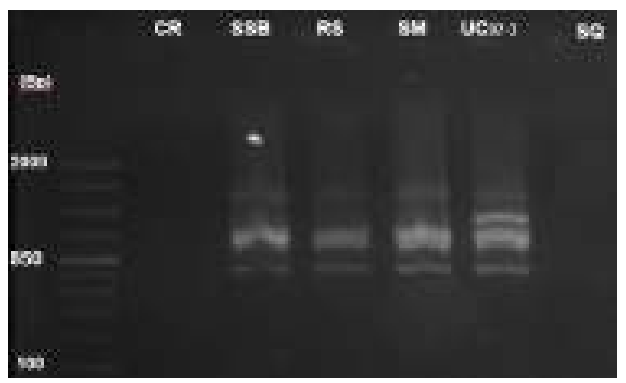

C) ISSR-3

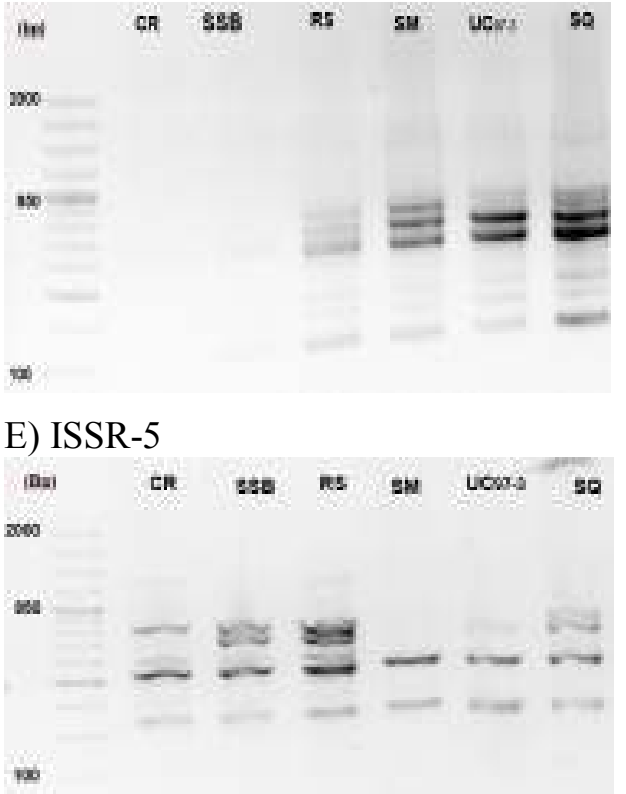

G) ISSR-7

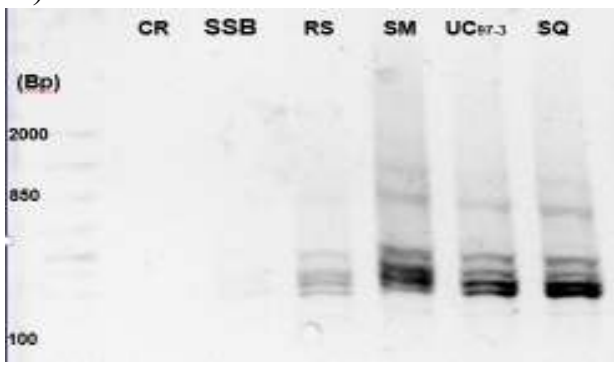

I) ISSR-9

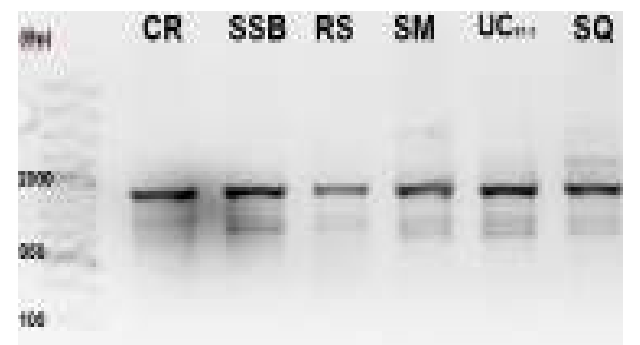

El-Argaa, et al.

B) ISSR-2

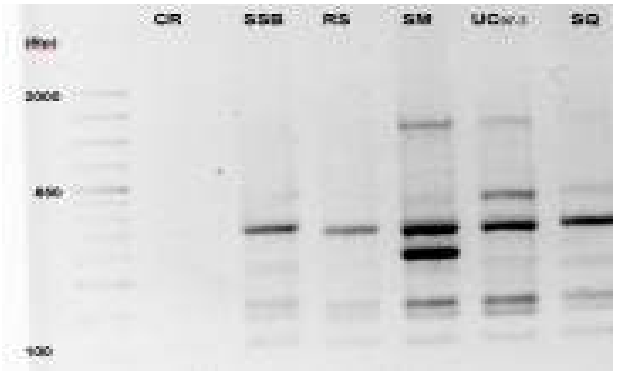

D) ISSR-4

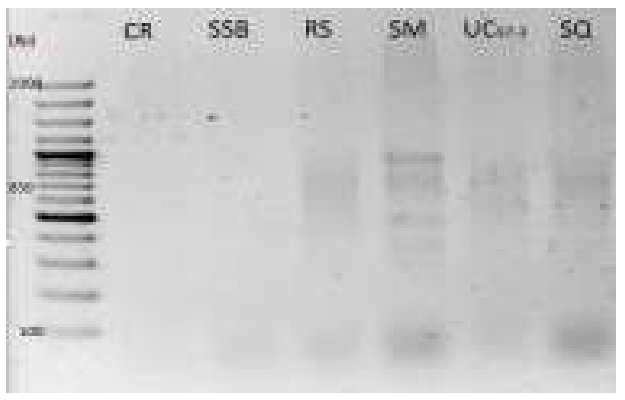

F) ISSR-6

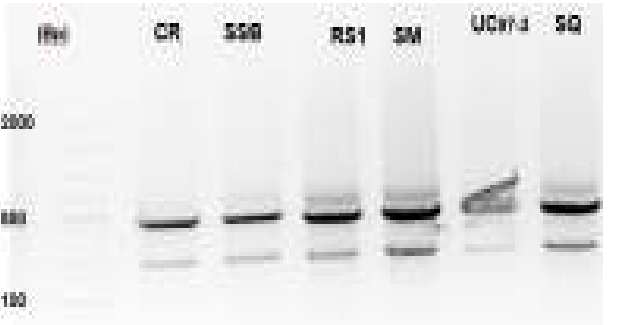

H)ISSR-8

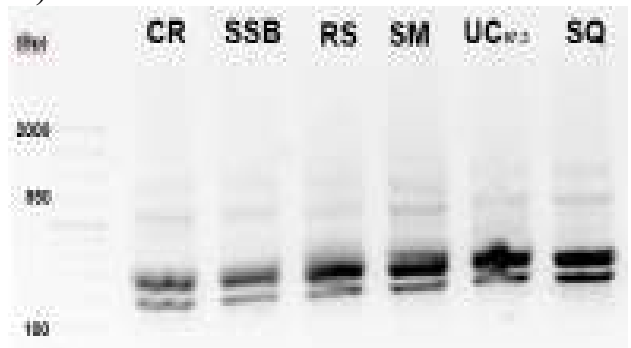

J) ISSR-10

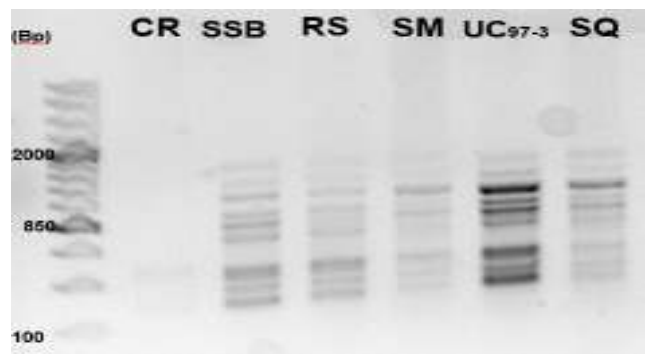

Fig. 1. Profiles of DNA amplification of 6 S. lycopersicon cultivars (agarose gel $1.5 \%$, stained with ethidium bromide). A,B,C,D,E,F,G,H,I,J 
Table 12. ISSR primers, number of total amplified bands, number of monomorphic bands, number of Polymorphic bands, number of unique bands and percentage of polymorphism

\begin{tabular}{lccccc}
\hline Primer name & $\begin{array}{c}\text { Number of } \\
\text { bands }\end{array}$ & Monomorphic Polymorphic & $\begin{array}{c}\text { Unique unique } \\
\text { band }\end{array}$ & $\begin{array}{c}\text { Polymorphism } \\
(\%)\end{array}$ \\
\hline ISSR-1 & 9 & 0 & 8 & 1 & 100 \\
ISSR-2 & 12 & 0 & 11 & 1 & 100 \\
ISSR-3 & 15 & 0 & 12 & 3 & 100 \\
ISSR-4 & 11 & 0 & 7 & 4 & 100 \\
ISSR-5 & 10 & 2 & 7 & 1 & 70 \\
ISSR-6 & 5 & 2 & 2 & 1 & 50 \\
ISSR-7 & 9 & 0 & 8 & 1 & 100 \\
ISSR-8 & 9 & 1 & 7 & 1 & 77.78 \\
ISSR-9 & 9 & 1 & 8 & 0 & 88.89 \\
ISSR-10 & 9 & 1 & 8 & 0 & 88.89 \\
Total & 98 & 7 & 78 & 13 & 91.76 \\
\hline
\end{tabular}

Table 13. The similarity coefficient values among all cultivars and new lines based on band polymorphisms generated by ISSR after using the primers

\begin{tabular}{lcccccc}
\hline & SM & RS & SSB & UC $_{\text {97-3 }}$ & CR & SQ \\
\hline SM & 1 & 0.75 & 0.35 & 0.25 & 0.80 & 0.82 \\
RS & & 1 & 0.235 & 0.43 & 0.65 & 0.75 \\
SSB & & 1 & 0.79 & 0.35 & 0.54 \\
UC 97-3 $_{\text {CR }}$ & & & 1 & 0.45 & 0.27 \\
SQ & & & & & 1 & 0.89 \\
\hline
\end{tabular}




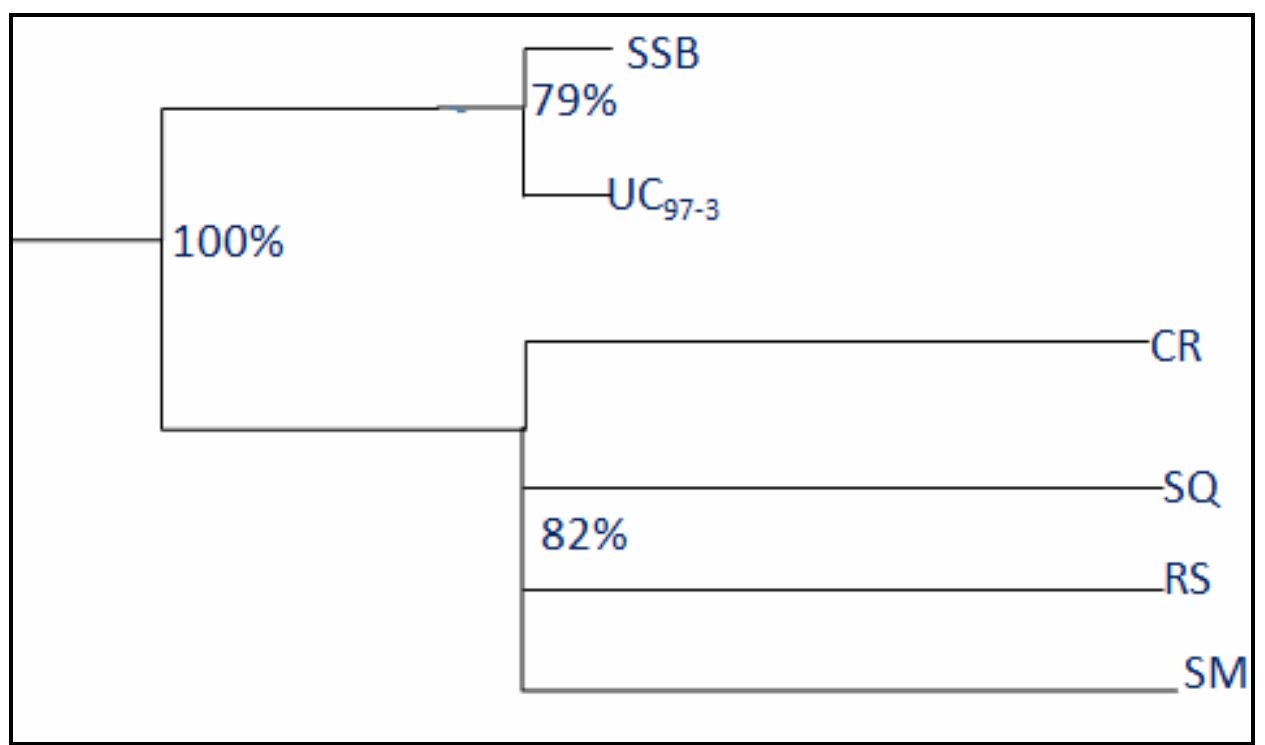

Fig. 2. Phylogenetic tree displaying the similarity of tomato cultivars. The tree was constructed using primer

\section{REFERENCES}

Abdel-Raheem, A.T., A.R. Ragab, Z.A. Kasem, F.D. Omar and A.M. Samera (2007). In vitro selection for tomato plants for drought tolerance via callus culture under polyethylene glycol (PEG) and mannitol treatments. Afri. Crop Sci. Conf. Proc., 8 : 2027- 2032.

Adams, P., J.C. Thomas, D.M. Vernon, H.J. Bohnert and R.G. Jensen (1992). Distinct cellular and organismic responses to salt stress. Plant Cell Physiol., 33: 1215-1223.

Bhatia, P., N. Ashwath, T. Senaratna and D. Midmore (2004). Tissue culture studies of tomato (Lycopersicon esculentum). Plant Cell, Tissue and Organ Culture, $78: 1-21$.

Davis, D.G., K.A. Breiland, D.S. Frear and G.A. Secor (1994). Callus initiation and regeneration of tomato (Lycopersicon esculentum) cultivars with different sensitivities to metribuzin. Plant Growth Reg. Soc. Ame. Quarterly, 22:65 - 73.

Devi, M., M.S. Dhaliwal, A. Kaur and S.S. Gosal (2008). Effect of growth regulators on In vitro morphogenic response of tomato. Indian J. Biotechnol., 7: 526-530.

Doyle, J.J. and J.L. Doyle (1987). A rapid DNA isolation procedure for small quantities of fresh leaf tissue. Phytochemical Bulletin, 19 : 11-15.

FAO (2012). Statistical Database FAOSTAT: Production-Crops, 2012 data. Food and Agric. Organ. United Nat.

Gamborg, O.L.F., J.P. Shyluk, D.S. Brar and F. Consble (1977). Morphogenesis and plant regeneration from callus of immature embryos of sorghum. Plant Sci. Lett., 10:67 -41 .

George, E.F. and P.D. Sherrington (1984). Plant Propagation by Tissue Culture-Handbook and Directory of Commercial Laboratories. VIII + 709 S., 12 Abb., 40 Tab. Eversley, Basingstoke 1984. Exegetics Limited. ISBN: 0-9509325-0-7

Gomez, K.A. and A.A. Gomez (1984). Statistical Procedures for Agriculture Research $2^{\text {nd }} \mathrm{Ed}$. John Wiley and Sons, New York, 146-184.

Holdgate, D.P. (1977). Propagation of ornamentals by tissue culture. In Applied and Fundamental Aspects of Plant, Cell, Tissue and Organ Culture, Ed.J. Reinert and YPS Bajaj, Springer-Verlag, New York,18 - 43.

Ishag, S., M.G. Osman and M.M. Khalafalla (2009). Effects of growth regulators, explant and genotype on shoot regeneration in tomato (Lycopersicon esculentum CV. Omdurman) Int. J. Sustain Crop Prod., 4(6): 7-13. 
Kamel, M.A. (2004). Genetic studies on tissue culture in tomato. M. Sc. Thesis, Fac. Agric., Zagazig Univ., Egypt.

Khaled, A.M.K. and A.M.H. Esh (2008). High quality genomic DNA impurities-free from sugar crops and other plant tissue. In: $3^{\text {rd }}$ International Conference IS-2008 "Meeting the Challenges of Sugar Crops and Integrated Industries in Developing Countries", Organizing by International Association of Professionals in Sugar and Integrated Technologies (IAPSIT), 11-14 ${ }^{\text {th }}$ September, 2008, Al-Arish, Egypt, pp 330-332 Khaled A M Khaled; I.S. El-Demardash, E.A.M.

Kochieva, E.Z., N.N. Ryzhova, I.A. Khrapalova and V.A. Pukhalskyi (2002). Genetic diversity and phylogenetic relationships in the genus Lycopersicon (Tourn.) Mill. as revealed by inter-simple sequence repeat (ISSR) analysis. Russian J. Genet., 38 (8): 958-966

Koornneef, M. (1987). In O'Brien. S.J. (ed.), Genetic Maps. Cold Spring Harbor Laboratory Press. Cold Spring Harbor, NY, 4: $742-745$.

Koornneef, M., J. Bade, C. Hanhart, K. Horsman, J. Schel, W. Soppe, R. Verkerk and P. Zabel (1993). Characterization and mapping of a gene controlling shoot regeneration in tomato. Plant J., 3: 131-141.

Kurtz, S.M. and R.D. Lineberger (1983). Genotypic differences in morphogenic capacity of cultured leaf explants of tomato. J. Ametican Soc. Hort. Sci., 108 : 5-710714.

Moghaieb, E.A., S. Hirofumi and F. Kounosuke (1999). Plant regeneration from eypocotyl and cotyledon explant of tomato (Lycoperation esculantum Mill). Soil Sci. Plant Nut., 45 (3): 639- 646.

Murashige, T. (1974). Plant propagation through tissue culture Ann. Rev. Plant Physiol., 25: 135- 166.

Murashige, T. and F. Skoog (1962). A revised medium for rapid growth and bioassays with tobacco tissue culture. Physiol. Plant, 15 : $473-479$.
Park, C., R. Crooks, E.J. Siochi, J.S. Harrison, E. Kenik and N. Evans (2003). Nanotechnol., 14 : L11.

Plastira, V.A. and A.K. Perdikaris (1997). Effect of genotype and explants type in regeneration frequency of tomato in vitro. Acta Hort., 231-234,

Rhodes, D. (2002). Tomatoes-Notes (Purdue University).http://www.hort.purdue.edu/rhod cv/hort410/tomat/to00001.htm.

Schutze, R. and G. Wieczorrek (1987). Plant regeneration in plated callus primary suspensions of the cultivated tomato (Lycopersion esculentum, Mill cv. Nadja) independence on phytohormone content Archiv. Fur Zuchtungsforshung., 17: 185 190.

Singh, R.S., M. Choudhary and J.R. David (1987). Contrasting patterns of geographic variation in the cosmopolitan sibing species Drosophila melanogaster and D simulans. Biochem. Genet., 25: 27-40

Skoog, F. and C.O. Miller (1957). Chemical regulation of growth and organ formation in plant tissue cultivated in vitro. Symp. Biol., 11: 118- 131 .

Terzopoulos, P.J. and P.J. Bebeli (2008). Genetic diversity of Mediterranean faba bean (Vicia faba L.) swith ISSR markers. Field Crops Res., 108: 39-44.

Thrope, T.A. (1993). In vitro organogenesis and somatic embryogenesis: Physiological and biochemical aspects. In morphogenesis in plants, Ed. Roubelakis-Angelakis-Angelakis, K.A and K. Tran Than Van, Plenum Press, New York, 19-38.

Tikunov, Y.M., L.I. Khrustaleva and G. Karlov (2003). Application of ISSR markers in the genus Lycopersicon. Euphytica, 131 (1): 7181.

Tran, T., K. Van and T.H. Trinh (1986). Fundamental and applied aspects of differentiation in vitro and in vivo. In Handbook of Cell Culture, Ed.D. Evans, W.R. Sharp, and. P.V Ammirato, Macmillan Publishing Company, New York, 317 - 335. 
Using A Priori Contrasts for Multivariate Repeated-Measures ANOVA to Analyze Thermoregulatory Responses of the Dibbler (Parantechinus apicalis; Marsupialia, Dasyuridae) Author (s): Philip C. Withers and Christine E. Cooper Reviewed work(s): Source: Physiological and Biochemical
Zoology, Vol. 84, No. 5 (September/October 2011) : 514-521

Williams, J.G.K., A.R. Kubelik, K.J. Livak, J.A. Rafalski and S.V. Tingey (1990). DNA polymorphisms amplified by arbitrary primers are useful as genetic markers. Nucleic Acids Res., 18: 6531-6535.

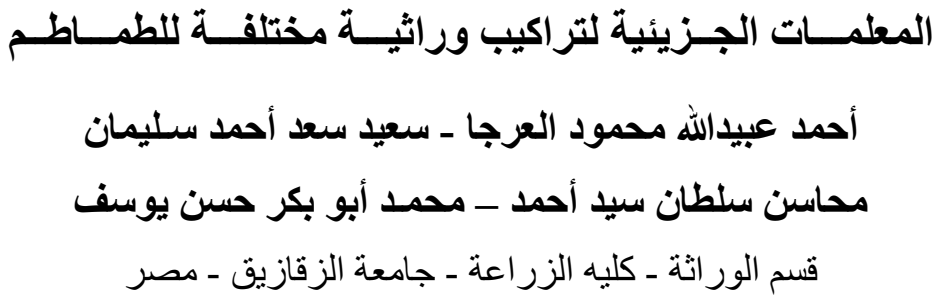

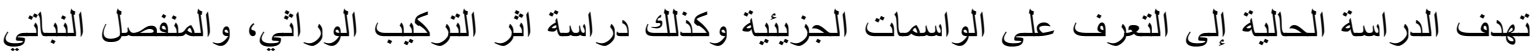

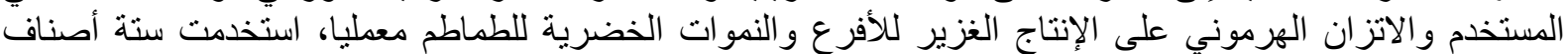
تجارية من الطماطم في التجربة محل الدراسة و هي SMB و تم استخدام نوعين من المنفصلات النباتية في التجربة هما القمة النامية

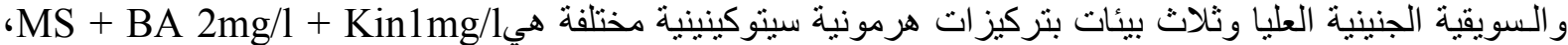
MS+ BA1mg/1 + Kin2 mg/1 ، MS + BA 0.5mg/1 + Kin0.5mg/1

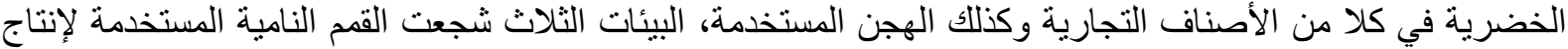

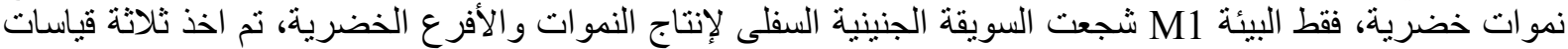

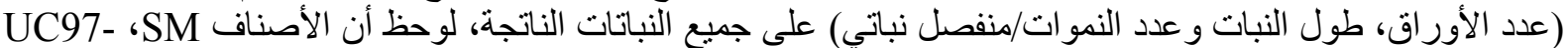

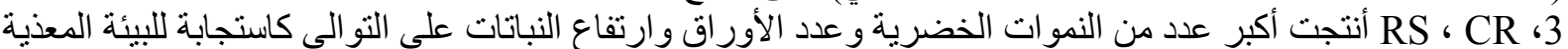

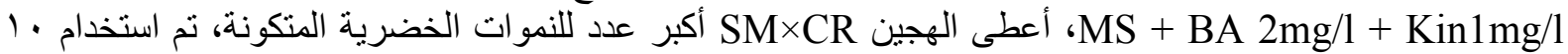

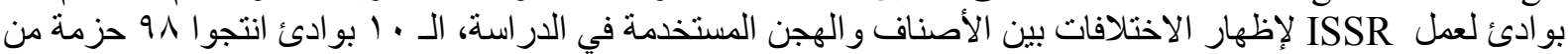

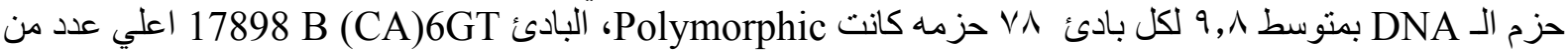

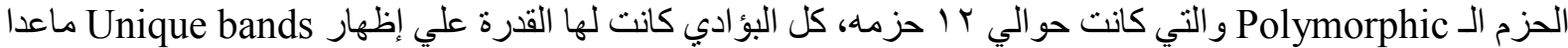

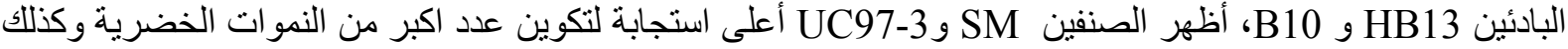

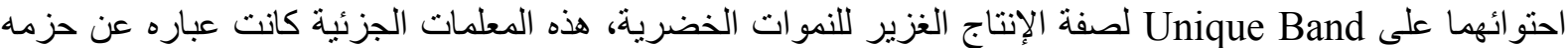

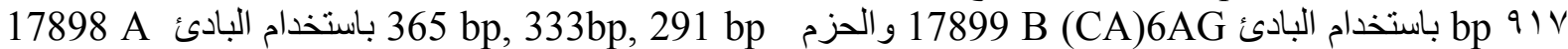

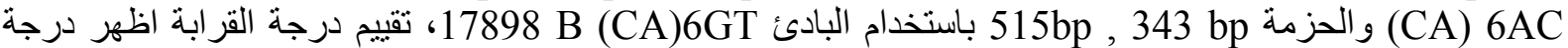

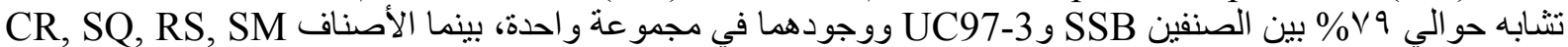

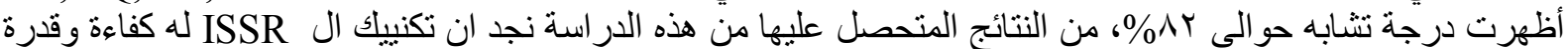

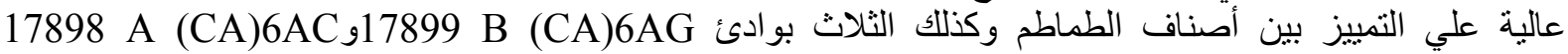

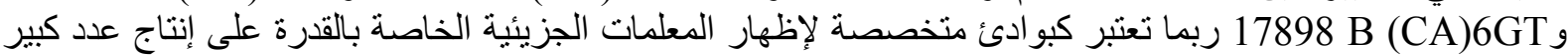
من الأفرع و النمو ات الخضرية للتر اكيب الور اثية للطماطم.

أستاذ الور اثة المتفر غ - كلية الزر اعة - جامعة كفر الثيخ. أستاذ ورئيس قسم الور اثة ـ كلية الزراعة - جامعة الزفة الزقازيق. 